\title{
ORTODONTINIO GYDYMO REIKALINGUMO INDEKSO IOTN NAUDOJIMAS TARP LIETUVOS ORTODONTŲ IR ODONTOLOGIJOS STUDENTŲ
}

\author{
Simona Šefeldaitė $\dot{1}^{1}$, Arūnas Vasiliauskas ${ }^{2}$ \\ ${ }^{1}$ Lietuvos sveikatos mokslu universiteto Odontologijos fakultetas, \\ ${ }^{2}$ Lietuvos sveikatos mokslu universiteto Ortodontijos klinika
}

Raktažodžiai: ortodontinio gydymo reikalingumo indeksai, IOTN EK, IOTN DK.

\begin{abstract}
Santrauka
Tyrimo tikslai: įvertinti Lietuvos gydytojų ortodontų ir ortodontijos specialybės gydytojų rezidentų žinias apie ortodontinio gydymo reikalingumo indeksą (IOTN) ir jo taikymą klinikinejje praktikoje. Palyginti, kaip Lietuvos sveikatos mokslų universiteto Medicinos akademijos Odontologijos fakulteto 5 kurso odontologijos studentai ir Lietuvos gydytojai ortodontai vertina ortodontinio gydymo reikalingumo indekso (IOTN) estetinį komponentą.

Tyrimo medžiaga ir metodai: sukūrus autorinę anketą apklausti Lietuvos gydytojai ortodontai ir ortodontijos specialybès 1-3 kurso gydytojai rezidentai bei Lietuvos sveikatos mokslų universiteto paskutinio kurso odontologijos studentai. Gydytojų anketą sudarè keturios dalys: 1 dalis - demografiniai duomenys; 2 dalis IOTN naudojimas ar nenaudojimas, tokio pasirinkimo priežastys; 3 dalis - IOTN estetinio komponento (EK) vertinimas; 4 dalis - dantų būklès komponento (DK) vertinimas. Tiriamieji turejo dešimt estetinio komponento nuotraukų išrikiuoti nuo patraukliausios iki nepatraukliausios ir nuotraukas suskirstyti $i \underset{\text { tris }}{\text { gru- }}$ pes: mažo gydymo reikalingumo, vidutinio, didelio reikalingumo. Dantų būklès komponentui ịvertinti 23 požymiai iš IOTN DK lentelès buvo išrikiuoti atsitiktine tvarka ir specialistai buvo paprašyti priskirti juos penkiems vertinimo laipsniams. Cohen'o Kappa buvo taikyta palyginti atsakymų sutapimą su ,auksiniu" standartu (angl. golden standard), t.y. IOTN EK ir DK. İvertinti, ar yra statistiškai reikšmingos sąsajos, buvo atliktas chi kvadrato testas. Statistinè analizė atlikta SPSS programa. Reikšmingumo lygmuo $\mathrm{p}<0,05$.
\end{abstract}

Rezultatai: iš 110 anoniminių apklausos anketų ortodontams, atsakytos $29(26,3 \%)$ ir iš 90 anketų studentams, atsakytos 68 (75,5\%). Dauguma apklaustujų yra girdejję apie IOTN indeksą. Vidutinis Cohen'o Kappa koeficientas (IOTN pritaikymo balas) vertinant IOTN DK ortodontams buvo 0,320. Vidutinis Cohen'o Kappa koeficientas IOTN EK tarp gydytoju rikiuojant nuotraukas nuo patraukliausios iki nepatraukliausios tarp gydytojų buvo 0,414 , tarp studentų 0,495 , grupuojant nuotraukas pagal gydymo reikalingumo kategoriją koeficiento reikšmè tarp gydytojų buvo 0,373 , o tarp studentų 0,424 . Dideli suderinamumą su ,auksiniu“ standartu, išrikiuojant IOTN EK nuotraukas turejo $6(20,7 \%)$ ortodontai ir $25(36,7 \%)$ studentai. Grupuojant IOTN EK nuotraukas pagal gydymo reikalingumą, tik 2 (9\%) gydytojai ir 13 $(23,5 \%)$ studentų turèjo vidutinị ir didesnị suderinamumą su standartu.

\section{Ivadas}

Ortodontinio gydymo reikalingumo indeksai yra plačiai naudojami pasaulyje. Jie yra skirti gydytojams odontologams specialistams įvertinti dantų bei sąkandžio anomalijas ir estetiką. Remiantis atliktų tyrimų duomenimis, Lietuvoje netaisyklingo sąkandžio paplitimas $61,7-77 \%$ [1]. Daugiau nei pusè besikreipiančiujjų i odontologą skundžiasi dantų estetinemis problemomis [2]. Tačiau gydytojas ir pacientas dantų būklę gali interpretuoti skirtingai. Nuspręsti, kada reikia nukreipti pacientą ortodontiniam gydymui, padeda ortodontinio gydymo reikalingumo indeksai. Jie taip pat padeda suskirstyti pacientus pagal gydymo reikalingumą [3-6]. Užsienio šalyse (Jungtinėje Karalystėje, Skandinavijoje) tokie indeksai naudojami tarp bendrosios praktikos gydytojų odontologų bei ortodontų kaip teisinis kriterijus siekiant ortodontinio gydymo finansavimo [5,7]. Šiuo metu dažniausiai naudojami indeksai yra Dantų estetikos indeksas 
(angl. Dental Aesthetic Index DI) ir Ortodontinio gydymo reikalingumo indeksas (angl. lndex of Orthodontic Treatment Need, IOTN). Pastarajį sudaro estetinis ir dantų būklès komponentai, kurie padeda gydytojams įvertinti kiekvieno paciento atveji pagal gydymo reikalingumo kategoriją ir patrauklumo lygi $[1,2]$. Ortodontinio gydymo reikalingumo indeksai Lietuvoje nèra privalomi, tačiau ateityje galètų būti pasitelkiami efektyvesniam ortodontinio gydymo planavimui.

Uždaviniai: 1. Ivvertinti, kaip gydytojai geba pritaikyti IOTN indekso estetinị ir dantų būklès komponentus. 2. Palyginti, kaip LSMU MA OF 5 kurso odontologijos studentai ir Lietuvos ortodontai vertina ortodontinio gydymo reikalingumo indekso IOTN estetinio komponento nuotraukas pagal patrauklumo lygi. 3. Palyginti, kaip tiriamieji grupuoja IOTN estetinio komponento nuotraukas pagal gydymo reikalingumo kategorijas.

Darbo tikslai: ịvertinti Lietuvos gydytojų ortodontų ir ortodontijos specialybės gydytojų rezidentų žinias apie ortodontinio gydymo reikalingumo indeksą ir indekso taikymą klinikinejje praktikoje bei palyginti, kaip Lietuvos sveikatos mokslų universiteto Medicinos akademijos Odontologijos fakulteto (LSMU MA OF) 5 kurso odontologijos studentai ir Lietuvos gydytojai ortodontai vertina ortodontinio gydymo reikalingumo indekso IOTN estetinị komponentą.

\section{Tyrimo medžiaga ir metodai}

Tyrimui buvo išduoti Bioetikos leidimai Nr. BEC-OF-68 ir Nr. BEC-OF-67. Atlikus literatūros apžvalgą, sukurta autoriné anketa $[3,8]$. Tyrimo metu apklausti Lietuvos gydytojai ortodontai ir ortodontijos specialybès 1-3 kurso gydytojai rezidentai bei Lietuvos sveikatos mokslų universiteto paskutinio kurso odontologijos studentai. Gydytojų anketą sudare keturios dalys: 1 dalis - demografiniai duomenys; 2 dalis - IOTN indekso naudojimas ar nenaudojimas, tokio pasirinkimo priežastys; 3 dalis - IOTN estetinio komponento (EK) vertinimas; 4 dalis - dantų būklès komponento (DK) vertinimas. Studentai vertino tik estetinį komponentą. Buvo išdalinta 110 anoniminès apklausos anketų gyd. ortodontams ir 90 anketų odontologijos studentams.

Tyrimą sudare dvi dalys: estetinio ir dantų būklès kom-

1 lentelè. Gydytojų ortodontų ir ortodontijos specialybės gydytojų rezidentų demografiniai duomenys.

\begin{tabular}{|c|c|c|c|c|}
\hline Am & $\begin{array}{l}\text { Iki } 30 \text { metur } \\
10(34,5 \%)\end{array}$ & $\begin{array}{c}30-40 \text { metuc } \\
8(27,6 \%) \\
\end{array}$ & $\begin{array}{l}40-50 \text { metur } \\
10(34,5 \%) \\
\end{array}$ & $\begin{array}{c}\text { per } 50 \text { metų } \\
1(3,4 \%)\end{array}$ \\
\hline & $\begin{array}{c}<5 \text { metai } \\
11(37,9 \%)\end{array}$ & $\begin{array}{l}5-10 \\
5(17\end{array}$ & $\begin{array}{c}10-20 \text { metur } \\
9(31 \%)\end{array}$ & $\begin{array}{c}\text { per } 20 \text { metų } \\
4(13,8 \%)\end{array}$ \\
\hline $\begin{array}{l}\text { Darbo- } \\
\text { viené }\end{array}$ & $\begin{array}{c}\text { Privati gyd. } \\
\text { istaiga } \\
11(37,9 \%)\end{array}$ & $\begin{array}{l}\text { Valstybine } \\
\text { gyd. ịstaiga } \\
5(17,2 \%)\end{array}$ & \multicolumn{2}{|c|}{$\begin{array}{c}\text { Privati ir valstybine } \\
\text { gyd. îstaiga } \\
13(44,8 \%)\end{array}$} \\
\hline
\end{tabular}

ponentų vertinimas tarp gydytojų ortodontų ir estetinio komponento vertinimo palyginimas tarp gydytojų ortodontų ir LSMU MA OF penkto kurso studentų. Dešimt estetinio komponento nuotraukų buvo išdèliotos atsitiktine tvarka, o visi tiriamieji jas turèjo išrikiuoti nuo patraukliausios iki nepatraukliausios. Tuomet buvo paprašyta nuotraukas suskirstyti i tris grupes: mažo gydymo reikalingumo (pirma), vidutinio (antra), didelio reikalingumo (trečia). Dantų būklès komponentui įvertinti atsitiktine tvarka išrikiuoti 23 požymiai iš IOTN DK lentelès ir specialistai buvo paprašyti priskirti juos penkiems vertinimo laipsniams (nuo 1 - gydymo nereikia iki 5 - labai didelis gydymo reikalingumas).

Aprašomosios statistikos metodas buvo taikytas apskaičiuoti kiekvieno atsakymo pasiskirstymą. Atskirai vertinti estetinis ir dantų būklès komponentai. Cohen'o Kappa taikyta kiekvienam tiriamajam atskirai ir palygintas atsakymų sutapimas su ,auksiniu“" standartu (angl. golden standard), t.y. anksčiau gydytojų konsiliumo sukurtu indeksu [3]. Ivertinti, ar yra statistiškai reikšmingos sąsajos tarp respondentų grupių ir pasirinktų atsakymų buvo atliktas chi kvadrato testas. Visi duomenys buvo suvesti i Excel programą, statistinè analizė atlikta SPSS programa. Reikšmingumo lygmuo $\mathrm{p}<0,05$.

\section{Rezultatai}

Iš 110 anoniminių apklausos anketų gydytojams ortodontams atsakytos $29(26,3 \%)$ ir is 90 anketų studentams atsakytos 68 (75,5\%). Dauguma apklaustų gydytojų ir 62 studentai yra girdèję apie IOTN indeksą. Dvidešimt (69\%) ortodontų ir $62(43,4 \%)$ studentai yra girdejję apie gydymo reikalingumo, sudètingumo ir rezultatų indeksą (angl. Index of Complexity, Outcome and Need, ICON), ir tik 7 (24\%) gydytojai ir $23(16,1 \%)$ penktakursiai yra girdèję apie funkcini ortognatinio reikalingumo indeksą (angl. Index of Orthognathic Functional Treatment Need, IOFTN).

IOTN žinios ir dantų būklès komponento panaudojimas tarp gydytojų ortodontų. Gydytojų ortodontų amžius, darbo patirtis ir darbo vieta pateikiami 1 lenteleje. Septyni $(24,1 \%)$ iš atsakiusiuju niekada nėra naudoję indekso, keturiolika $(48,2 \%)$ - studijų metu, dešimt specialistų $(34,5 \%)$ tekę naudoti ir klinikineje praktikoje po studijų. Penki (17,2\%) specialistai pažymejjo, kad nenaudoja indekso, nes tai neprivaloma, trijų (10,3\%) ortodontų nuomone tai užima per daug laiko, ir vienas specialistas atsake, jog tai yra per sunku. Vienuolika (37,9\%) ortodontų mano, kad svarbu naudoti indeksą bei pažymėjo, jog tai padètų skirstyti pacientus pagal gydymo sunkumą, komunikuojant su pacientais. Taip pat iš indekso naudojimo priežasčių buvo išskirta jo taikymas moksliniuose tyrimuose (vienas atsakymas) ir siekiant finansavimo iš Teritorinių ligonių kasų (TLK) (du atsakymai). Dešimt (31\%) specialistų mano, kad indeksas reikšmès 
klinikinejje praktikoje neturi ir tiek pat gydytojų neturèjo nuomonès. Didžioji dauguma respondentų (62\%) nenaudoja IOTN savo klinikinejje praktikoje.

Buvo ịvertintas dantų būklès komponento pritaikymas. Vidutinis Cohen'o Kappa koeficientas (IOTN pritaikymo balas) buvo 0,320. Remiantis Landis ir Koch metodika [9], 0,416 Cohen - Kappa indeksas atitinka nuo patenkinamo iki vidutiniško suderinamumo. Didelis suderinamumas su „auksiniu“ standartu laikomas nuo 0,61. Koeficiento pasiskirstymas tarp atsakiusiujų pateikiamas 1-ame paveiksle.

Estetinio komponento vertinimo palyginimas tarp ortodontų ir penkto kurso studentų. Vidutinis Cohen'o Kappa koeficientas EK gydytojams buvo 0,414 ir 0,373, o studentams 0,495 ir 0,424. Didelį suderinamumą su ,auksiniu“ standartu, išrikiuojant IOTN EK (I) (2 paveikslas) nuotraukas nuo patraukliausios iki nepatraukliausios, turejo $6(20,7 \%)$ ortodontai ir $25(36,7 \%)$ studentai. Grupuojant IOTN EK (II) (3 paveikslas) nuotraukas pagal gydymo reikalingumą, tik $2(9 \%)$ gydytojai ir $13(23,5 \%)$ studentų turèjo vidutini ir didesnị suderinamumą su standartu. Atlikus chi-kvadrato testą, statistiškai reikšmingas skirtumas gautas skirstant i grupes 4-tą ( $\mathrm{p}=0,028), 5$-tą $(\mathrm{p}=0,013), 7$-tą $(\mathrm{p}=0,006)$ ir 8-tą $(\mathrm{p}=0,004)$ nuotraukas. IOTN EK 5 -ta nuotrauka žymi ribą, nuo kurios gydymas reikalingas, o 8-ta nuotrauka - būtinas ortodontinis gydymas. Dešimt studentų (14,7\%) 4-tą nuotrauką teisingai priskyre pirmai grupei, 47 studentai $(69,1 \%)$ priskyrė antrai grupei ir net vienuolika $(16,1 \%)$ trečiai grupei. Tuo tarpu ortodontai atsake tiksliau: $34,5 \%$ priskyrè pirmai grupei, $41,4 \%$ antrai ir $27,1 \%$ trečiai reikalingumo kategorijai. Penktają nuotrauką $6(20,7 \%)$ ortodontai ir tik du $(2,9 \%)$ studentai priskyre pirmai grupei, tuo tarpu teisingai grupei priskyrè $15(51,7 \%)$ gydytojų ir $39(57,4 \%)$ studentai. Septintają nuotrauką net 62 studentai $(91,2 \%)$

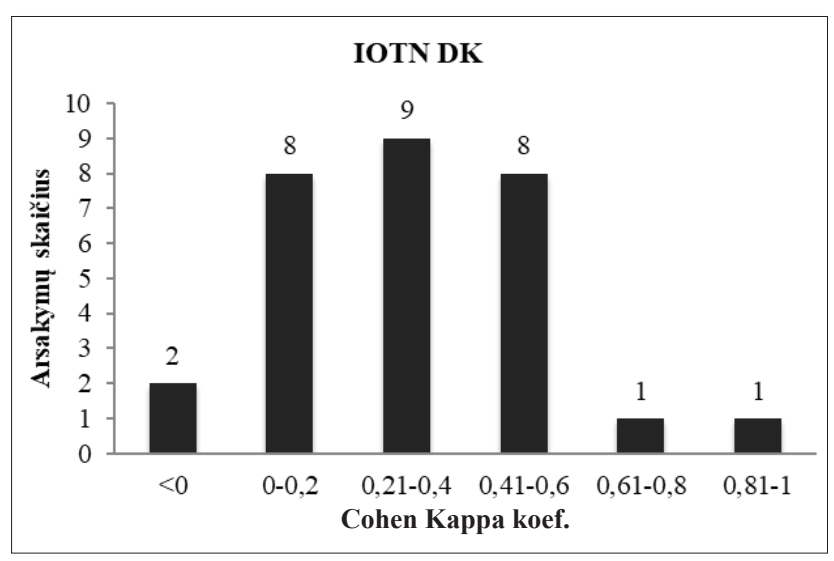

1 paveikslas. Gydytojų ortodontų IOTN dantų būklès komponento pritaikymo balų rezultatai. neteisingai priskyrè trečiai grupei, o iš ortodontų teisingai sugrupavo devyni (31\%), likę dvidešimt (69\%) pažymèjo trečią grupę. Aštuntają nuotrauką $62(92,6 \%)$ studentai ir $20(69 \%)$ gydytojų teisingai priskyre trečiai grupei, keturi $(13,8 \%)$ ortodontai pažymejo antrą grupę ir net $17,2 \%$ pirmą gydymo reikalingumo kategoriją.

\section{Diskusija}

Daugiau nei trečdalis apklaustų ortodontų turèjo mažesnę nei penkerių metų darbo patirtį, tuo tarpu trečdalio apklaustụjų darbo patirtis buvo 10-20 metų. Dèl to sunku spręsti, ar rezultatams galejo turetti ịtakos gydytojų darbo patirtis. Trečdalis gydytojų dirbo tik privačioje gydymo įstaigoje. Likusi dalis gydytojų specialistų dirbo tik valstybineje arba privačioje ir valstybinèje įstaigose. Mažas procentas naudojančiųų indeksą galètų reikšti, kad valstybinèse gydymo ìstaigose nèra taikomi universalūs priimti ortodontinio gydymo reikalingumo standartai.

Gydytojų ortodontų dantų būklès komponento vertinimo

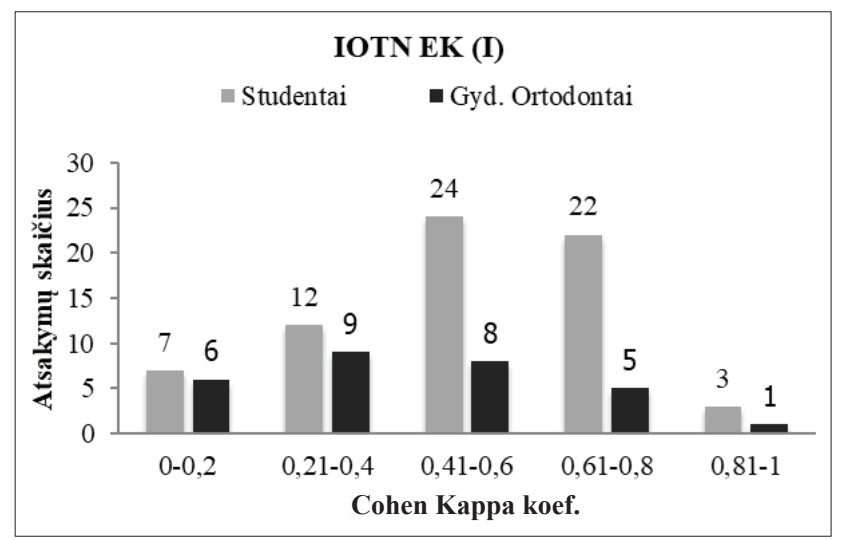

2 paveikslas. Estetinio komponento palyginimas rikiuojant nuotraukas nuo patraukliausios iki nepatraukliausios.

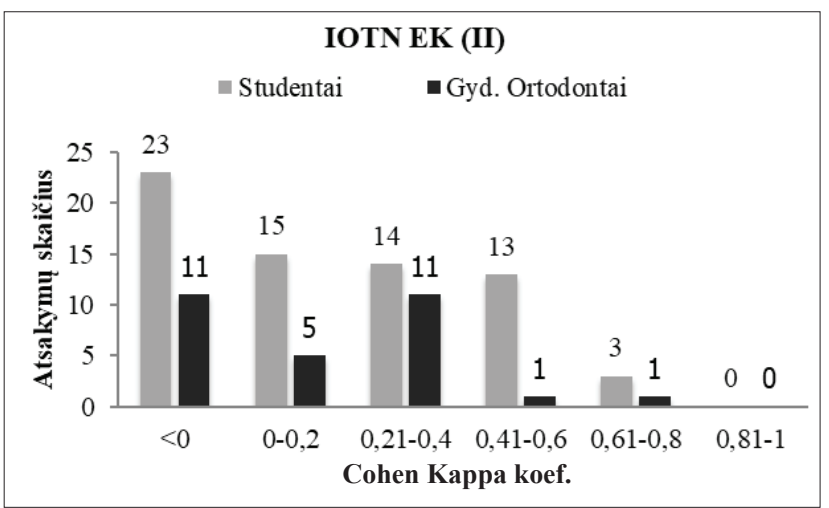

3 paveikslas. Estetinio komponento palyginimas grupuojant nuotraukas pagal gydymo reikalingumą. 
balas buvo ypač žemas. Tik $7 \%$ ortodontų turèjo vidutinị suderinamumą su ,auksiniu“ standartu, šie duomenys panašus i Š Škotijoje atlikto tyrimo, kuriame 10,5\% respondentu Cohen'o Kappa koeficientas buvo didesnis už 0,61 [5].

Lyginant rezultatus tarp gydytojų ir studentų, rezultatai buvo patenkinami. Statistiškai reikšmingas skirtumas rastas vertinant būtent tas nuotraukas, kurios žymi ribas tarp trijų gydymo reikalingumo grupių (gydymo nereikia/mažas gydymo reikalingumas; vidutinis gydymo reikalingumas; didelis gydymo reikalingumas). Švedijoje atliktame tyrime ribinę ketvirtą nuotrauką teisingai priskyre gydymo reikalingumo kategorijai 70,1\% apklaustujų, o 26,6\% pažymėjo antrą kategoriją [7]. Šie duomenys smarkiai skiriasi nuo mūsų tyrimo atsakymų, kur neteisingai kategorijai pritaikiusiujų skaičius buvo didesnis abiejose tiriamųų grupèse. Švedų ortodontai penktą nuotrauką teisingai sugrupavo tik $23,7 \%$, o mažą gydymą reikalingumą rinkosi $72,5 \%$. Mūsų tyrimo rezultatai buvo geresni - pusė apklaustų ortodontų ir daugiau nei pusè studentų atsakymai atitiko indekso kategoriją. Septintą nuotrauką, esančią paskutine vidutinio gydymo reikalingumo grupèje, teisingai įvertino panašus procentas ortodontų kaip ir Švedijos tyrime (23,7\%), tačiau tarp studentų didžioji dauguma rinkosi trečią gydymo reikalingumo grupę. Aštuntos nuotraukos vertinime Lietuvos odontologijos studentai nuotrauką teisingai priskyre didelio gydymo reikalingumo kategorijai dažniau, nei gydytojai, taip surinkę beveik panašius rezultatus ị ankstesnio tyrimo, kuriame visi ortodontai atsakè teisingai. Atsižvelgiant ị mūsų tyrimo duomenis, 1-3 nuotraukos turetų būti priskirtos mažo gydymo reikalingumui/gydymo nereikia, 4-6 nuotraukos vidutinio ir 7-10 nuotraukos didelio gydymo reikalingumui.

İdomu tai, jog gydytojų ortodontų rezultatai buvo prastesni už studentų. Žemas suderinamumas su ,auksiniu“ standartu, tai yra IOTN indekso pritaikymo standartu, galètu reikšti, jog apklaustieji nebuvo pakankamai apmokyti naudotis indeksu. Nors didžioji dauguma respondentų yra girdejję apie šį indeksą, jo netaiko klinikinejje praktikoje, todèl žinių ir igūdžių neturèjimas galejjo lemti prastus rezultatus. Svarbu atsižvelgti į tai, jog nuotraukų patrauklumo vertinimas yra subjektyvus, todèl tai taip pat yra indekso trūkumas. Šis indeksas gali būti rekomenduojamas pacientams ịvertinti jų pačių dantų estetinị vaizdą, tačiau nesant stipraus sutarimo tarp gydytojų specialistų, pacientų konsultavimas pasitelkiant ortodontinio gydymo reikalingumo indekso estetini komponentą būtų netikslus.

Lietuvoje ortodontinio gydymo reikalingumo indeksai nèra plačiai naudojami kaip kitose šalyse, todèl akivaizdu, jog šalių, kuriose šio indekso taikymas yra privalomas, gydytojų ortodontų rezultatai buvo geresni. Geresni paskutinio kurso odontologijos studentų rezultatai galètų reikšti, jog būsimi gydytojai geriau pritaikè indeksą ir ateityje įvedus privalomą indekso taikymą, pacientų siuntimas pas gydytoją specialistą bus sklandesnis ir efektyvesnis. Reikalingas ortodontų ir būsimų gydytojų mokymas taikyti ortodontinio gydymo reikalingumo indeksą.

\section{Išvados}

1. Mūsų tyrimo rezultatų duomenimis, Lietuvos ortodontai blogai pritaiko ortodontinio gydymo reikalingumo indekso (IOTN) komponentus.

2. Studentų ir gydytojų ortodontų ortodontinio gydymo reikalingumo indekso estetinio komponento vertinimo pagal patrauklumo lygị rezultatai buvo patenkinami.

3. Gydytojai ortodontai ortodontinio gydymo reikalingumo indekso estetinio komponento nuotraukas pagal priekinių dantų estetiką dažniau nei studentai priskyrè žemesnei gydymo reikalingumo kategorijai.

\section{Literatūra}

1. Baubinienè D. Ortodontinių anomalijų paplitimas ir gydymo reikalingumas tarp Lietuvos moksleivių. Daktaro disertacija. Lietuvos sveikatos mokslų universitetas. Kaunas, 2010.

2. Petronytė D, Trakinienè G. Patient and parent motivation for orthodontic treatment and agreement between orthodontist, parent, patient perception using IOTN AC. Sveikatos mokslai, 2017;27:57-62.

https://doi.org/10.5200/sm-hs.2017.011

3. Brook PH, Shaw WC. The development of an index of orthodontic treatment priority. Eur J Orthod 1989;11:309-320.

https://oi.org/10.1093/oxfordjournals.ejo.a035999

4. Järvinen S. Indexes for orthodontic treatment need. Am J Orthod Dentofac Orthop 2001;120:237-239. https://doi.org/10.1067/mod.2001.114830

5. Puri A, Ho-A-Yun J, McGuinness NJ. Use and knowledge of IOTN among GDPs in Scotland. Br Dent J 2015;218:399-404. https://doi.org/10.1038/sj.bdj.2015.247

6. Ho-A-Yun J, Crawford F, Clarkson J. The use of the index of orthodontic treatment need in dental primary care. Br Dent $\mathrm{J}$ 2009;206.

https://doi.org/10.1038/sj.bdj.2009.310

7. Johansson AM, Follin ME. Evaluation of the aesthetic component of the Index of Orthodontic treatment need by Swedish orthodontists. Eur J Orthod 2005; 27:160-166.

https://doi.org/10.1093/ejo/cjh095

8. Richmond S, Shaw WC, O'Brien KD, Buchanan IB, Stephens $\mathrm{CD}$, Andrews M. Roberts CT. The relationship between the Index of Orthodontic treatment need and consensus opinion of a panel of 74 dentists. Br Dent J 1995; 178:370. https://doi.org/10.1038/sj.bdj.4808776

9. Landis R, Gary K. The measurement of observer agreement for categorical data. Biometrics 1977;159-174.

https://doi.org/10.2307/2529310 
KNOWLEDGE AND USE OF INDEX OF ORTHODONTIC TREATMENT NEED AMONG LITHUANIAN ORTHODONTISTS AND ODONTOLOGY STUDENTS S. Šefeldaitė, A. Vasiliauskas

Keywords: index of orthodontic treatment need, IOTN Summary

The aims of the study were to evaluate the knowledge of the index of orthodontic treatment need (IOTN) and its application in clinical practice by Lithuanian orthodontists and post-graduate students. To compare the application of the aesthetic component of the index of orthodontic treatment need (IOTN AC) among Lithuanian University of Health Sciences Medical Academy Faculty of Odontology (LSMU MA OF) 5th year students and Lithuanian orthodontists.

Research methods: Literature review was performed and the questionnaire was created. Lithuanian orthodontists, post-graduate students of orthodontic speciality and LSMU MA OF final year odontology students were surveyed. The doctor's questionnaire consisted of four parts: part 1 - demographic data; part 2 - use or non-use of IOTN, the reasons for such choice; part 3 - assessment of the IOTN aesthetic component (AC); part 4 - assessment of dental health component (DHC). Photographs from IOTN AC were randomly ordered and subjects were asked to arrange them from the most attractive to the least attractive and to divide the photographs into three groups: low, medium and high treatment need. Traits from the IOTN DHC table were randomly ordered and specialists were asked to assign them to five grades. Cohen Kappa was used to compare the agreement with the golden standard - IOTN $\mathrm{AC}$ and DHC. To assess whether there is a statistically significant difference, a chi square test was performed. Statistical analysis was performed by SPSS program. Level of significance was $p<0.05$.

The results: The response rate for orthodontists was $29(26.3 \%)$ out of 110 and for students $68(75.5 \%)$ out of 90 . Most of the respondents have heard about the IOTN. The average Cohen Kappa coefficient (IOTN adaptation score) for the IOTN DHC among orthodontists was 0.320 . When arranging the photographs from the most attractive to the least attractive the average Cohen Kappa coefficient for IOTN AC was 0.414 among the doctors and 0.495 among the students. When dividing the photographs into three groups the average coefficient was 0.373 among the doctors and 0.424 among the students. Six (20.7\%) orthodontists and 25 (36.7\%) students achieved high compatibility with the gold standard when arranging the photographs. When grouping the photographs according to the need for treatment, only $2(9 \%)$ doctors and $13(23.5 \%)$ students had average and higher compatibility with the standard.

Conclusions: 1. According to the results of our research, Lithuanian orthodontists poorly apply the components of the index of orthodontic treatment need. 2 . The results of the assessment of the aesthetic component of the index of orthodontic treatment need by students and orthodontists were satisfactory. 3. Orthodontists have assigned the photographs of the aesthetic component of the index of orthodontic treatment need to the lower treatment need more often than the of students.

Correspondence to: simona.sefeldaite@gmail.com

Gauta 2019-05-21 